\title{
Study on Main Pollutants and Water Quality of Landscape Waterbody in Suzhou Ancient City
}

\author{
Guosheng $\mathrm{Ma}^{\mathrm{a}}$, Juan Chen ${ }^{\mathrm{b}, *}$ \\ Suzhou Polytechnic Institute of Agriculture, Suzhou, Jiangsu, 215008 \\ aemail:goshinema@163.com, ${ }^{\text {bemail:39340830@qq.com }}$ \\ ${ }^{*}$ Corresponding author
}

Keywords: Suzhou ancient city, landscape waterbody, pollutants, water quality.

\begin{abstract}
The water system of Suzhou ancient city is vertical and horizontal. There are many water networks composed of large and small rivers, which have the functions of production, life and landscape. Taking the landscape water body of Suzhou ancient city as the research object, the national standard analysis method was used to compare the seven indicators of $\mathrm{pH}$, permanganate index, dissolved oxygen, ammonia nitrogen, total phosphorus, volatile phenol and petroleum with the surface water environmental quality standards. The results show that the water quality of the rivers in Suzhou ancient city is generally $\mathrm{V}$ or inferior $\mathrm{V}$. Among them, ammonia nitrogen pollution is the most serious, far exceeding the $\mathrm{V}$ water quality standard, up to $7.7 \mathrm{mg} / \mathrm{L}$; organic pollution is more serious, all are IV to $\mathrm{V}$ water quality. The ammonia nitrogen and permanganate index in water and the content of petroleum and volatile phenolic pollutants generally have a linear relationship.
\end{abstract}

\section{Introduction}

The ancient city of Suzhou has been in the water village. It has been a famous water city since ancient times. In 514 BC, Wu Zixu established an ancient Suzhou city with a slightly longer north and south and a slightly shorter east and west. In ensuring the source of living water, it can flow through the ancient city faster, thus ensuring the water quality of the ancient city. According to the calculation of the Pingjiang Map of Song Dynasty, the river in the ancient city was about $82 \mathrm{~km}$, with six vertical and twelve horizontal ones, shaped like a chessboard ${ }^{[1]}$.Today, the total length of the river in the ancient city is only $35.12 \mathrm{~km}$, with three vertical and three horizontal ones ${ }^{[1]}$, the length is shortened, the width is narrowed, and the main function has been transformed from waterway and domestic water into landscape water.

In the past two decades, the water quality of the ancient city of Suzhou has deteriorated, and a large amount of sewage has been discharged into the river. It is one of the water-deficient cities. Despite the increase in environmental protection in recent years, water treatment capacity and effectiveness have improved, but due to population growth and economic development, production and domestic water consumption has reached an unprecedented level, and sewage discharge has increased ever since. The water environment has become an important factor restricting the social and economic development of Suzhou. The water that can meet the requirements for production and domestic water use is less than half, and water in most rivers has lost the use value. 


\section{Materials and Methods}

\subsection{Reagent solutions}

2.1.1 Acid solutions. $1.84 \mathrm{~g} / \mathrm{mL}$ sulfuric acid, $1 \mathrm{~mol} / \mathrm{L}$ sulfuric acid, $1+3$ sulfuric acid, $1+1$ sulfuric acid, $1+5$ sulfuric acid, $1.18 \mathrm{~g} / \mathrm{mL}$ hydrochloric acid, $6 \mathrm{~mol} / \mathrm{L}$ hydrochloric acid, $1+5$ hydrochloric acid, $1.4 \mathrm{~g} / \mathrm{mL}$ nitric acid, $1.70 \mathrm{~g} / \mathrm{mL}$ phosphoric acid, $1.68 \mathrm{~g} / \mathrm{mL}$ perchloric acid, $100 \mathrm{~g} / \mathrm{L}$ ascorbic acid.

2.1.2 Alkaline solution. $500 \mathrm{~g} / \mathrm{L}$ sodium hydroxide, $1 \mathrm{~mol} / \mathrm{L}$ sodium hydroxide, $6 \mathrm{~mol} / \mathrm{L}$ sodium hydroxide, $50 \mathrm{~g} / \mathrm{L}$ sodium hydroxide, $10 \%$ sodium hydroxide, $40 \%$ sodium hydroxide.

2.1.3 Salt solutions. $0.1 \mathrm{~mol} / \mathrm{L}$ Potassium bromate - potassium bromide, $0.0125 \mathrm{~mol} / \mathrm{L}$ potassium iodate, $0.0125 \mathrm{~mol} / \mathrm{L}$ sodium thiosulfate, $50 \mathrm{~g} / \mathrm{L}$ potassium persulfate, molybdate solution, $10 \mathrm{~g} / \mathrm{L}$ volatile phenolphthalein solution, $0.5 \mathrm{~g} / \mathrm{L}$ methyl orange indicator solution, starch solution, $10 \%$ copper sulfate, $130 \mathrm{~g} / \mathrm{L}$ aluminum sulfate, anhydrous magnesium perchlorate, anhydrous sodium sulfate sulphate, potassium iodide, sodium chloride, magnesium sulfate.

2.1.4 Standard solutions. Sodium oxalate standard solution, potassium permanganate standard solution, phosphorus standard solution, nitrite nitrogen standard stock solution, bromic acid mixture.

2.1.5 Other reagents. Anhydrous ethanol, N-hexadecane, 14-tetramethylpentadecane, ether, methane, carbon tetrachloride, hypobromite oxidant.

\subsection{Instrument and equipment}

Gas phase molecular absorption spectrometer, , spectrophotometer, infrared spectrophotometer, $\mathrm{pH}$ meter, Water bath, dissolved oxygen meter, $500 \mathrm{~mL}$ all glass distiller, and $1000 \mathrm{~mL}$ separatory funnel.

\subsection{Sampling method}

The six main rivers of Suzhou ancient city were continuously sampled and sampled by water sampler from mid-April to May, once every half month, and continuously sampled three times to calculate the average value.

\subsection{Test methods}

2.4.1 $\mathrm{pH}$. The $\mathrm{pH}$ meter method ${ }^{[2]}$ 。

2.4.2 COD $_{\mathrm{Mn}}$. Permanganate index method ${ }^{[2]}$. The permanganate index in the sample was calculated by the formula IMn.

2.4.3 $\mathrm{NH}_{3}-\mathrm{N}$. Gas phase molecular absorption spectroscopy method ${ }^{[2]}$. The ammonia nitrogen standard curve was directly plotted with a nitrite nitrogen standard solution, and the absorbance of the sample was compared with a standard curve.

2.4.4 TP. Ammonium molybdate spectrophotometry method ${ }^{[2]}$.

2.4.5 DO. Dissolved oxygen meter ${ }^{[2]}$.

2.4.6 Volatile phenol. Bromination volume method after distillation ${ }^{[2]}$.

2.4.7 Petroleum. Infrared spectrophotometry method ${ }^{[2]}$.

\section{Results and Analysis}

\subsection{Test results and analysis of main pollution}

The test results of seven indexes such as $\mathrm{pH}$, permanganate index, dissolved oxygen, ammonia nitrogen, total phosphorus, volatile phenol and petroleum in the water samples from the ancient city of Suzhou were listed in Table 1, Table 2 and Table 3.

Table $1 \mathrm{COD}_{\mathrm{Mn}}$ and DO determination results of landscape waterways in Suzhou ancient city

\begin{tabular}{cccccccc}
\hline Project & \multicolumn{6}{c}{ Sampling point } & Average \\
\cline { 2 - 7 } & $\begin{array}{c}\text { Loujiang } \\
\text { River }\end{array}$ & $\begin{array}{c}\text { Wuque } \\
\text { Bridge }\end{array}$ & $\begin{array}{c}\text { Shanjia } \\
\text { Bridge }\end{array}$ & $\begin{array}{c}\text { Cufang } \\
\text { Bridge }\end{array}$ & $\begin{array}{c}\text { Renmin } \\
\text { Bridge }\end{array}$ & $\begin{array}{c}\text { Guangji } \\
\text { Bridge }\end{array}$ & $\begin{array}{c}\text { (variable } \\
\text { amplitude) }\end{array}$ \\
\hline $\mathrm{pH}$ & 7.5 & 7.6 & 7.9 & 7.6 & 7.8 & 7.4 & $7.6(7.4-7.9)$
\end{tabular}




\begin{tabular}{cccccccc}
$\mathrm{DO}(\mathrm{mg} / \mathrm{L})$ & 2.2 & 3.6 & 1.5 & 2.4 & 4.7 & 4.0 & $3.07(1.5-4.7)$ \\
$\mathrm{COD}_{\mathrm{Mn}}(\mathrm{mg} / \mathrm{L})$ & 7.7 & 8.2 & 8.6 & 7.9 & 6.7 & 7.5 & $7.63(6.7-8.6)$ \\
\hline
\end{tabular}

Note: The $\mathrm{pH}$ is dimensionless.

It can be seen from Table 1 that the water in the main landscape rivers of Suzhou ancient city is weakly alkaline, with a $\mathrm{pH}$ between 7.4 and 7.9; the lowest water DO is $1.5 \mathrm{mg} / \mathrm{L}$, the highest is 4.7 $\mathrm{mg} / \mathrm{L}$; the lowest $\mathrm{COD}_{\mathrm{Mn}}$ is $6.7 \mathrm{mg} / \mathrm{L}$, the highest is $8.6 \mathrm{mg} / \mathrm{L}$.

According to surface water environmental quality standards ${ }^{[3]}$, DO and $\mathrm{COD}_{\mathrm{Mn}}$ in all water of Suzhou ancient city are water quality below Class IV, and DO in the vicinity of Shanjia Bridge is the inferior Class V.

Table $2 \mathrm{NH}_{3}-\mathrm{N}$ and TP determination results of landscape waterways in Suzhou ancient city

\begin{tabular}{|c|c|c|c|c|c|c|c|}
\hline \multirow[t]{2}{*}{ Project } & \multicolumn{6}{|c|}{ Sampling point } & \multirow{2}{*}{$\begin{array}{c}\text { Average } \\
\text { (variable } \\
\text { amplitude) }\end{array}$} \\
\hline & $\begin{array}{l}\text { Loujiang } \\
\text { River }\end{array}$ & $\begin{array}{l}\text { Wuque } \\
\text { Bridge }\end{array}$ & $\begin{array}{l}\text { Shanjia } \\
\text { Bridge }\end{array}$ & $\begin{array}{l}\text { Cufang } \\
\text { Bridge }\end{array}$ & $\begin{array}{c}\text { Renmin } \\
\text { Bridge }\end{array}$ & $\begin{array}{c}\text { Guangji } \\
\text { Bridge }\end{array}$ & \\
\hline $\mathrm{NH}_{3}-\mathrm{N}(\mathrm{mg} / \mathrm{L})$ & 7.1 & 4.9 & 7.7 & 4.8 & 4.5 & 4.7 & $\begin{array}{c}5.62 \\
(4.5-7.7)\end{array}$ \\
\hline $\mathrm{TP}(\mathrm{mg} / \mathrm{L})$ & 0.30 & 0.14 & 0.09 & 0.14 & 0.08 & 0.11 & $\begin{array}{c}0.14 \\
(0.08-0.30)\end{array}$ \\
\hline
\end{tabular}

It can be seen from Table 2 that the nitrogen pollution in the main river landscape of the ancient city of Suzhou is serious, especially the ammonia nitrogen pollution is very serious.

According to the surface water environmental quality standard ${ }^{[3]}$, all ammonia nitrogen is the inferior Class $\mathrm{V}$, and greatly exceeds the water quality standard of $2.0 \mathrm{mg} / \mathrm{L}$ of Class $\mathrm{V}$, the highest reached $7.7 \mathrm{mg} / \mathrm{L}$; the degree of phosphorus pollution is low, except for the Loujiang River, all reached II Class or Class III water quality standards.

Table 3 Organic pollutants determination results of landscape waterways in Suzhou ancient city

\begin{tabular}{|c|c|c|c|c|c|c|c|}
\hline \multirow[t]{2}{*}{ Project } & \multicolumn{6}{|c|}{ Sampling point } & \multirow{2}{*}{$\begin{array}{c}\text { Average } \\
\text { (variable } \\
\text { amplitude) }\end{array}$} \\
\hline & $\begin{array}{l}\text {-oujiang } \\
\text { River }\end{array}$ & $\begin{array}{l}\text { Wuque } \\
\text { Bridge }\end{array}$ & $\begin{array}{l}\text { Shanjia } \\
\text { Bridge }\end{array}$ & $\begin{array}{l}\text { Cufang } \\
\text { Bridge }\end{array}$ & $\begin{array}{c}\text { Renmin } \\
\text { Bridge }\end{array}$ & $\begin{array}{c}\text { Guangji } \\
\text { Bridge }\end{array}$ & \\
\hline $\begin{array}{c}\text { Volatile } \\
\text { phenol(mg/L) }\end{array}$ & 0.07 & 0.11 & 0.17 & 0.09 & 0.05 & 0.07 & $\begin{array}{c}0.09 \\
(0.05-0.17)\end{array}$ \\
\hline Petroleum(mg/L) & 0.49 & 0.62 & 1.21 & 0.77 & 0.54 & 0.87 & $\begin{array}{c}0.75 \\
(0.49-1.21)\end{array}$ \\
\hline
\end{tabular}

It can be seen from Table 3 that the organic pollution of the main rivers in the ancient city of Suzhou is more serious.

According to the surface water quality standard ${ }^{[3],}$ all of them are water quality below Class IV, and the water pollution of the river near the Shanjia Bridge is the most serious.

The water quality volatile phenol in the river near the Wuque Bridge and near the Shanjia Bridge is the inferior Class V standard. The water quality of the petroleum near the Shanjia Bridge is the inferior Class V standard.

\subsection{Relationship among different pollutant indicators}

It can be seen from the change trend of different pollutants in the main rivers of Suzhou ancient city that the ammonia nitrogen and dissolved oxygen in the main river waters of Suzhou ancient city are basically in an anti-linear relationship, and the ammonia nitrogen concentration is high, and the dissolved oxygen content is low, and vice versa.

It can be also found from figure 1 that the content of ammonia nitrogen, permanganate index, petroleum and volatile phenolic pollutants are generally linear. But there is no linear relationship between ammonia nitrogen and total phosphorus. 


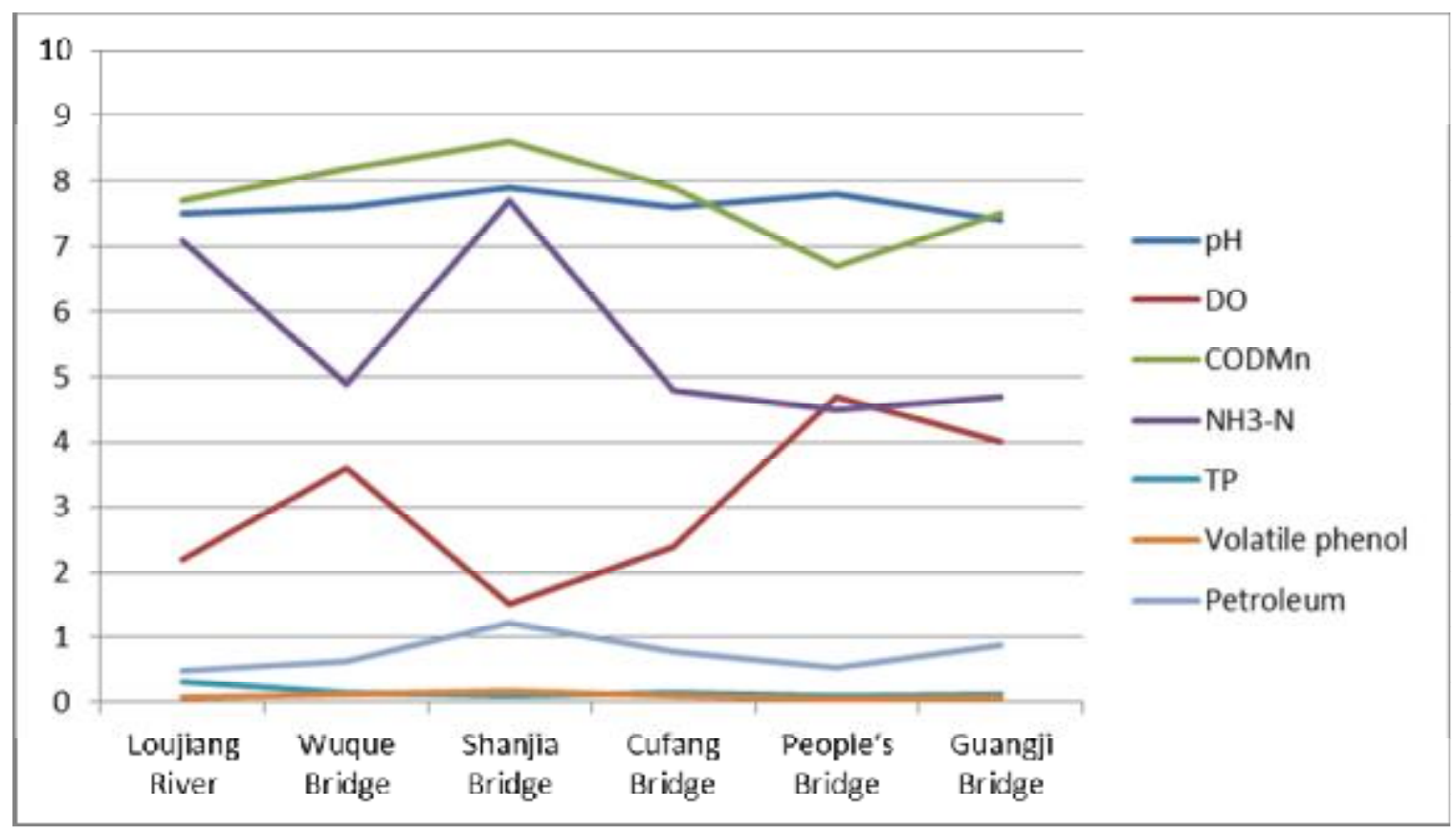

Figure 1 Change trends of different pollutants in the landscape rivers of Suzhou ancient city

\section{Results and Discussion}

4.1 The results show that most of the indicators of the river landscape in the ancient city of Suzhou exceed the national surface water environmental quality standards ${ }^{[3]}$, and most of them are $\mathrm{V}$ or the inferior $\mathrm{V}$ water.The research results are basically in line with people's personal experience and visual observation. Most of the water bodies in the ancient city appear brownish gray directly, accompanied by obvious impurities. Some rivers flowing through the communities and the rivers in the broken river also have a large amount of gas escape, and the pollution is more serious.

4.2 Judging from the research results, the main reason for the deterioration of the water environment in the ancient city of Suzhou is that a large amount of production and domestic sewage and organic pollutants, domestic garbage and excreta are dumped, which exceeds the self-purification ability of water bodies, and the ammonia nitrogen content is too high, and cyanobacteria often occur. In addition, the amount of water flowing through the ancient city channel is reduced, and the flow rate is slowed down, causing the water body to appear brown and black with stench and the water environment is rapidly deteriorating.

\section{Conclusions}

With the development of industrial economy and catering services, a large amount of sewage is discharged into the river, and various residents, units and vessels along the river dump various garbage into the river, and throw gravels, bricks, wooden sticks and even old furniture into the river, which deteriorated the water quality of the river and the riverbed was deposited, too. The water quality of Suzhou ancient city has deteriorated since the $1980 \mathrm{~s}{ }^{[4]}$.At the same time, as Taihu water diverted from the river of $\mathrm{Xu}$ River to the ancient city and diverted southward from the Grande Canale, the source of living water entering the ancient city was reduced by $57 \%$. In 2012, the water source of the ancient city of Suzhou was changed from the Taihu Lake and the Grand Canal in the early 1980s to the Yangtze River ${ }^{[5] .}$ The flow rate of the river was slowed down, the sediment was easy to deposit, causing the river bed to become shallow or even fouled. And the water level and downstream of the Fengqiao River in the upper reaches and the water level of the Midu Bridge is only a few ten centimeters apart, but a wooden float floats from upstream to downstream for more than 15 days.

According to reports ${ }^{[6]}$, by the end of June 2016, Suzhou water-saving enterprises, institutions and schools had covered $30 \%, 70 \%$ and $50 \%$ respectively. However, from the audit results ${ }^{[7]}$, it is 
impossible to evaluate the economics, efficiency and effectiveness of the use of financial input and control funds from the overall and long-term water quality changes.

It is believed in this study that we should first focus on improving the self-purification capacity of the ancient city water body, carry out comprehensive improvement of river water body and coastal environment, remove contaminated sediment and garbage, carry out ecological restoration of water bodies, and punish misbehavior and discharge personal credits for river discharge and garbage disposal so as to change the landscape of the river environment for a long time. At the same time, it is necessary to connect the production and domestic sewage into the qualified sewage pipe network, effectively improve the sewage interception rate, treatment rate and capital use efficiency, and upgrade the water quality standard of Suzhou ancient city to the Class III standard of surface water.

\section{Acknowledgements}

This research was financially supported by the "Qinglan Project" of Universities in Jiangsu province (Grant NO. 2016-15), Jiangsu province "333 High-level Personnel Training Project" (Grant NO. BRA2016489), and Jiangsu province "Six Talent Peaks Project” (Grant NO. 2016-NY-093).

\section{References}

[1] Suzhou Local History Compilation Committee: History of Suzhou City, Jiangsu People Press, Nanjing (1995)

[2] State Envi. Pro. Admi.: Water and Wastewater Monitoring and Analysis Methods, China Environmental Science Press, Peking (2002)

[3] State Envi. Pro. Admi.: Surface Water Environmental Quality Standard ,GB3838-2002

[4] Y.R. Xue: A Sub-topic Overview of the Research on the Comprehensive Prevention and Control Plan for Water Pollution in Suzhou City and Wuxian County and the Value of Garden Landscape Tourism, Environmental Science, Vol. 4(1983), p. 3

[5] SH. Shi, Z.W. Fan and J.X. Wu: Study on the Evolution Law of Water System and Hydrodynamic Improvement in Suzhou Gucheng District, People's Yangtze River, Vol. 9(2017), p. 20-24

[6] G.R. Wang: Suzhou "Water Efficiency Leader" Leading the Action to See Results, Leading Decision-making Information, Vol. 1(2017), p. 15

[7] Y.H. Sun: Strengthening Water Environment Audit to Promote the Construction of Suzhou Water Ecological Civilization City, Industry and Technology Forum, Vol. 6(2016), p. 192-193 